Received: 19-11-2021

\section{Research Article}

Accepted: 25-01-2021

To Cite: Dincer Ö, Celebioglu HU, Hamid A, Aftab MN, Karadağ A, 2021. Saccharification of Hazelnut and Rhododendron Biomasses Using $\beta$-xylanase from Thermotoga naphthophila. Journal of the Institute of Science and Technology, 11(2): $1321-1328$.

\title{
Saccharification of Hazelnut and Rhododendron Biomasses Using $\beta$-xylanase from Thermotoga naphthophila
}

Özgenur DİNÇER ${ }^{1}$, Hasan Ufuk CELEBIOGLU²*, Attia HAMID ${ }^{3}$, Muhammad Nauman AFTAB $^{4}$, Ahmet

\section{KARADA $\breve{G}^{5}$}

\begin{abstract}
Enzymes can be used in various biotechnological applications due to the easy and cheap production. Since xylanase enzymes are preferred in various industries, researchon this enzyme is extensively being carried out. In this study, the $\beta$-xylanase gene was cloned from Thermotoga naphthophila, a thermophilic organism. The expression vector pET21a(+) was expressed in Escherichia coli BL21 (DE3). As a result of the studies, the $\mathrm{pH}$, temperature and IPTG concentration of the enzyme were optimized to obtain highest expression. Dinitrosalicylic acid (DNS) was used to determine sugar content of the enzyme. The molecular mass of the purified $\beta$-xylanase enzyme was determined using sodium dodecyl sulfate (SDS) polyacrylamide gel electrophoresis. The molecular mass of the enzyme was calculated to be $38 \mathrm{kDa}$. Enzymatic hydrolysis of hazelnut shell, rhododendron branch and rhododendron leaves was performed. Released reducing sugar contents from the enzymatic hydrolysis were calculated as $0.8461 \mathrm{mg} \mathrm{mL}^{-1}, 0.6976 \mathrm{mg} \mathrm{mL}^{-1}$ and $0.3605 \mathrm{mg} \mathrm{mL}^{-1}$ for hazelnut shell, rhododendron branch, and rhododendron leaf respectively. In conclusion, $\beta$-xylanase enzyme can be an effective source for enzymatic hydrolysis to produce fermentable sugars from such biomasses.
\end{abstract}

Keywords: bioethanol, cloning, expression, saccharification, $\beta$-xylanase

\footnotetext{
'̈̈zgenur DINÇER (Orcid ID: 0000-0002-2598-4865), Bartın University, Department of Molecular Biology and Genetics, Bartın, Turkey

${ }^{2}$ Hasan Ufuk CELEBIOGLU (Orcid ID: 0000-0001-7207-2730), Bartın University, Department of Biotechnology, Bartın, Turkey

${ }^{3}$ Attia HAMID (Orcid ID: 0000-0001-8296-4791), Government College University Lahore, Department of Industrial Biotechnology, Lahore, Paksitan

${ }^{4}$ Muhammad Nauman AFTAB (Orcid ID: 0000-0002-6224-8496), Government College University Lahore, Department of Industrial Biotechnology, Lahore, Paksitan

${ }^{5}$ Ahmet KARADAĞ (Orcid ID: 0000-0003-4676-683X), Yozgat Bozok University, Department of Chemistry, Yozgat, Turkey.

*Sorumlu Yazar/Corresponding Author: Hasan Ufuk CELEBIOGLU, e-mail: ufukcelebioglu@gmail.com

This study was produced from MSc thesis of Özgenur DİNÇER.
} 


\section{INTRODUCTION}

Enzymes are biological catalysts that have important roles in shaping the life. They are also important for industrial processes. They are being used in paper, leather, textile, cleaning, food, feed, medicine, cosmetics, and biofuel industries (Jegannathan and Nielsen, 2013). It is advantageous to use enzymes of microbial origin, as opposed to enzymes obtained from animal and plant sources. Animal and plant tissues are limited but enzymes obtained from microbial sources are very diverse (Topal, 1985).

Lignocelluloses are mainly composed of cellulose, hemicellulose, and lignin. Specifically, lignin forms a physical barrier, limiting enzymes' accessibility to cellulose. Thus, removal of lignin from the structure is necessary to release fermentable sugars; thus, a pre-treatment process is required. The enzymatic hydrolysis processes are preferred to break down cellulose into simple sugars (Phitsuwan et al., 2016). According to Sun and Cheng (2002), the pretreatment method should increase the formation of fermentable sugar, without causing carbohydrate degradation, prevent the formation of by-products that will cause inhibition of hydrolysis and fermentation stages, and should be affordable. Xylan is used as a major biopolymer in practical applications, and by the degradation of xylan, many important products are obtained in varying amounts (Zafar et al., 2016). Xylanase are enzymes that carry out the hydrolysis of xylan, which is present together with the cellulose and lignin structure in the plant cell wall. For this reason, wood shavings, corn cobs, hazelnut shells, wheat and other plant waste sources are being used as substrates in bacterial enzyme production methods. Xylan is an important structural polymer of a plant. Xylanases and some microorganisms are being used for ethanol production by hydrolyzing xylan (Rani and Nand, 1996). It contains plenty of hemicellulose in its xylan structure. Therefore, it is of great importance to ensure the separation of xylan into sugars by bacteria that produce ethanol and efficient use of plant biomass for biofuel production (Dodd and Cann, 2009).

Thermotoga naphthophila is an anaerobic, hyperthermophilic gram-negative bacterium that can be obtained from underground reserves in Japan. The suitable temperature for the growth of bacteria ranges between $48-86^{\circ} \mathrm{C}$. The optimum $\mathrm{pH}$ for the growth is in the range of 5.4-9.0. However, it shows the best activity at pH 7.0 (Hamid and Aftab, 2019). Lignocellulosic biomass such as wood, plant, and agricultural industry is a renewable resource that is abundant in the world and less agricultural work is required for the production of these biomasses (Hoşgün et al., 2017). Secondly, generation of biomass is made with raw materials that have no effect on the food chain, namely woody biomass. Therefore, second generation bioethanol production has a very high potential. Hazelnut, whose cultivation dates back to ancient times in our country, has found the most suitable growing environment in the Black Sea region. Hazelnut shells consist of $43.1 \%$ lignin, $27.5 \%$ hemicellulose, $24.7 \%$ cellulose, $3.4 \%$ alcoholbenzene extracts and 1.4\% ash (Arslan and Saraçoğlu, 2010). On the other hand, rhododendron is included in the Rhododendron genus, and has many different flower and leaf structures that grow from the west to the east of the Black Sea forests. Some of the types of rhododendrons having a fairly wide spread in the world, especially east of the Black Sea in Turkey is common (Özbucak et al., 2009). Hazelnut shell, rhododendron branch and rhododendron leaves can be used as renewable, low-cost, highyield raw materials for producing fermentable sugars as lignocellulosic biomass. In addition, converting agricultural wastes into energy increases the value of waste materials and prevents air pollution.

Thus, the present study aimed to use hazelnut shell, rhododendron branch and rhododendron leaves as lignocellulosic biomass and investigate the saccharification potential of $\beta$-xylanase from Thermotoga naphthophila on these biomasses. 


\section{MATERIALS AND METHODS}

\section{Cloning and Expression of the Recombinant $\beta$-xylanase}

Cloning and expression of recombinant $\beta$-xylanase enzyme was re-performed as described previously (Hamid and Aftab, 2019). Briefly, genomic DNA of Thermotoga naphthophila was used as template to amplify $\beta$-xylanase gene by PCR. and purified by Thermo Scientific GeneJET gel extraction kit. $\beta$-xylanase gene was then ligated into pET21a(+) vector using restriction site of HindШ.

For cloning, E. coli BL21 was used after making the competent cells. Transformation of cloned $\beta$ xylanase gene was performed in the competent cells. The transformation was performed at $42^{\circ} \mathrm{C}$ by applying heat shock for 90 seconds. For confirmation of transformation, colony PCR was performed.

\section{Pretreatment of Biomasses with Acid-Alkaline Method}

The pre-treatment of biomass was carried out to remove the undesired structures in biomass. The pretreatment was applied to three different biomasses (hazelnut shell, rhododendron branch and rhododendron leaves). For the Acid-Alkaline method; $100 \mathrm{~mL}$ double distilled water was added in $2 \mathrm{~g}$ $\mathrm{NaOH}$ and dissolved. A $2 \mathrm{~g}$ of each biomass was weighed and taken into $50 \mathrm{ml}$ falcon tubes. $\mathrm{NaOH}$ solution was added in the tubes and shaken to make the contents uniform. The bottles were closed and autoclaved at $121^{\circ} \mathrm{C}$ for 15 minutes. In a separate bottle, $100 \mathrm{~mL}$ distilled water was added to $6.27 \mathrm{~mL}$ $37 \% \mathrm{HCl}$. The sterilized plant biomass was filtered through a Whatman filter paper. The supernatant was discarded and the solid contents were washed several times with distilled water. The $\mathrm{HCl}$ solution prepared to neutralize the $\mathrm{NaOH}$ mixture was taken into $20 \mathrm{~mL}$ shake flask and washed with double distilled water and shaken and kept for 30 minutes. The plant- $\mathrm{HCl}$ mixtures were washed with distilled water and filtered biomass was allowed to dry at room conditions for two days. Dried biomasses were crushed in pestle and placed in a $50^{\circ} \mathrm{C}$ oven for 15 minutes (Hoşgün et al., 2017).

\section{Saccharification of Pre-Treated Biomasses}

The amount of sugar released by the hydrolysis of the pretreated biomasses with the $\beta$-xylanase enzyme was analyzed. For saccharification of pre-treated biomasses, $0.1 \mathrm{~g}$ pre-treated biomass and 20 $\mathrm{mL} \beta$-xylanase enzyme were added into three beakers for each biomass. A $9 \mu 1$ chloramphenicol $(0.1$ $\mathrm{mg} \mathrm{mL} \mathrm{m}^{-1}$ ) antibiotic was added in beakers to prevent microbial growth. The beakers were kept in a shaking incubator at $60^{\circ} \mathrm{C}$ at $80 \mathrm{rpm}$ for 72 hours. Then biomasses were centrifuged at $3200 \mathrm{rpm}$ for 15 minutes. Supernatants were transferred to falcon tubes.

DNS was used to stop the enzyme's activity and to determine amount of sugar (Miller, 1959). In each flask, $1 \mathrm{~g}$ DNS was dissolved in $1.6 \mathrm{~g} \mathrm{NaOH}$. In another flask, $37.66 \mathrm{~g}$ of sodium potassium tartrate (Rochella salt) was dissolved in $50 \mathrm{~mL}$ distilled water. The content of the two flasks were mixed together, then heated and shaken until it became homogeneous.

$1 \mathrm{~mL}$ supernatants were added to empty falcon tubes and $1 \mathrm{~mL}$ prepared DNS was added. The tubes were kept in a water bath at $100^{\circ} \mathrm{C}$ for 5 minutes. The content was then allowed to cool at room temperature and later $8 \mathrm{~mL}$ distilled water was added in the tubes. Measurements were noted at $540 \mathrm{~nm}$ using a spectrophotometer. The calibration plot was made by measuring absorbances of different concentrations of glucose to adjust the sugar content of the unknown sample.

\section{RESULTS AND DISCUSSION}

\section{Recombinant Production of $\beta$-xylanase}

The recombinant colony was cultured in LB medium containing ampicillin, then sonicated and centrifuged. Since the recombinant $\beta$-xylanase enzyme was intracellular, cells were sonicated to release 
the intracellular enzyme. The partial purification of $\beta$-xylanase enzyme was carried out using the thermal method that also denatured host proteins.

Molecular mass determination of the purified $\beta$-xylanase enzyme was performed using SDSPAGE. Precision Plus Ladder (10-250 kDa) was used as a protein marker. As shown in Fig. 1, the molecular mass of $\beta$-xylanase samples with different amounts was examined. Protein samples were observed after staining with the gel staining solution containing Brilliant Blue dye. As a result of SDSPAGE, it was observed that the mass of $\beta$-xylanase was $38 \mathrm{kDa}$.

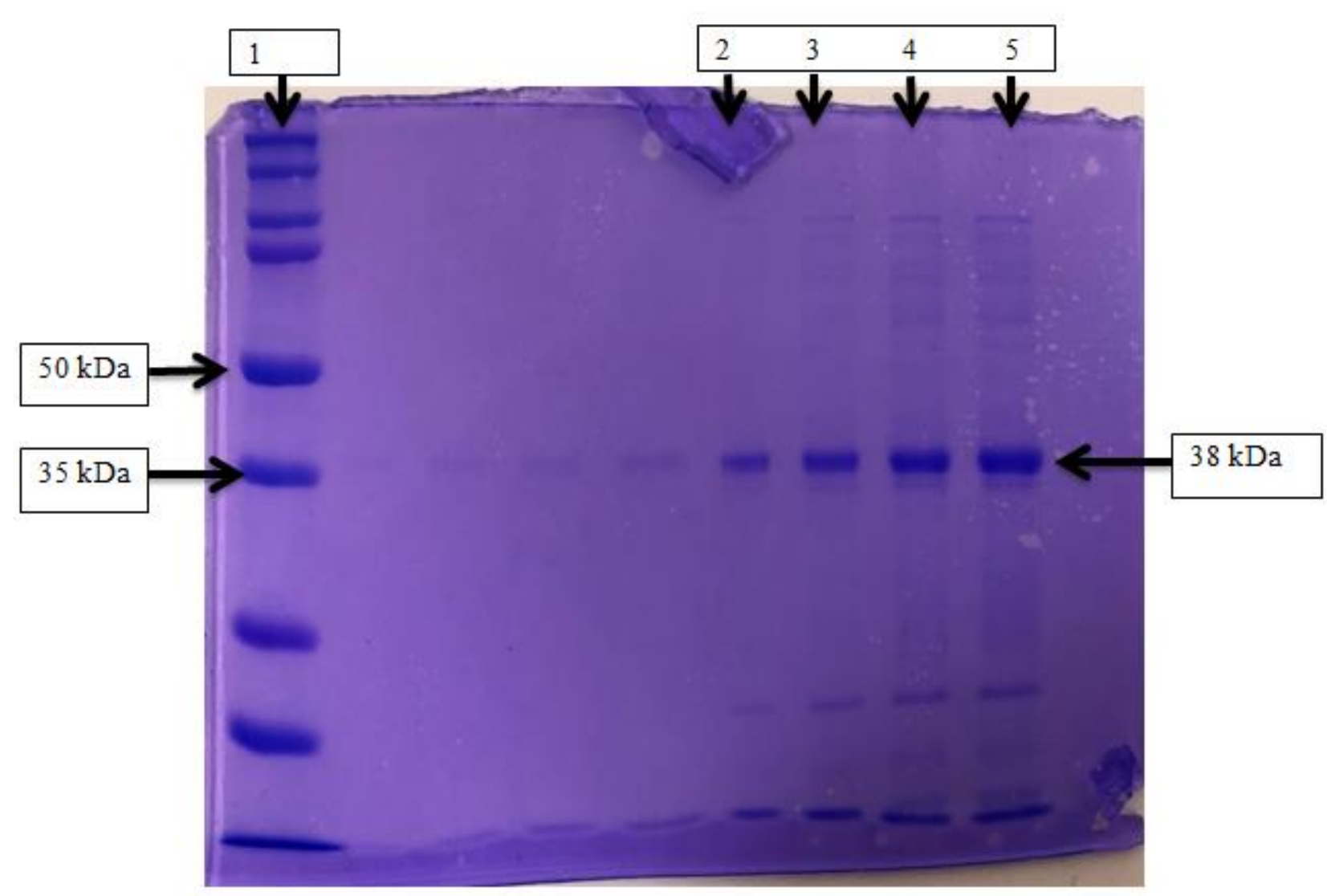

Figure 1. SDS-PAGE of partially purified $\beta$-xylanase. 1) protein marker 2) $5 \mu 1 \beta$-xylanase 3) $10 \mu 1 \beta$ xylanase 4) $15 \mu 1 \beta$-xylanase 5) $20 \mu 1 \beta$-xylanase

\section{Saccharification potential of $\beta$-xylanase over Biomasses}

DNS was used to measure the amount of sugar released after treatment of different biomass (nut cob, rhododendron branch, rhododendron leaves) with $\beta$-xylanase enzyme. The optical densities of hazelnut shell, rhododendron branch and rhododendron leaf biomasses measured at $540 \mathrm{~nm}$ in the spectrophotometer were $0.4604,0.3796$ and 0.1962 respectively. The sugar content of the biomass was determined as a result of the calibration graph drawn with different concentrations of glucose (Fig. 2).

Sugar content of biomass according to the calibration curve is given in Table 1. The highest reducing sugar amount was obtained for hazelnut shell $\left(0.8461 \mathrm{mg} \mathrm{mL}^{-1}\right)$, followed by rhododendron branch $\left(0.6976 \mathrm{mg} \mathrm{mL}^{-1}\right)$ and Rhododendron leaf $\left(0.3605 \mathrm{mg} \mathrm{mL}^{-1}\right)$. 


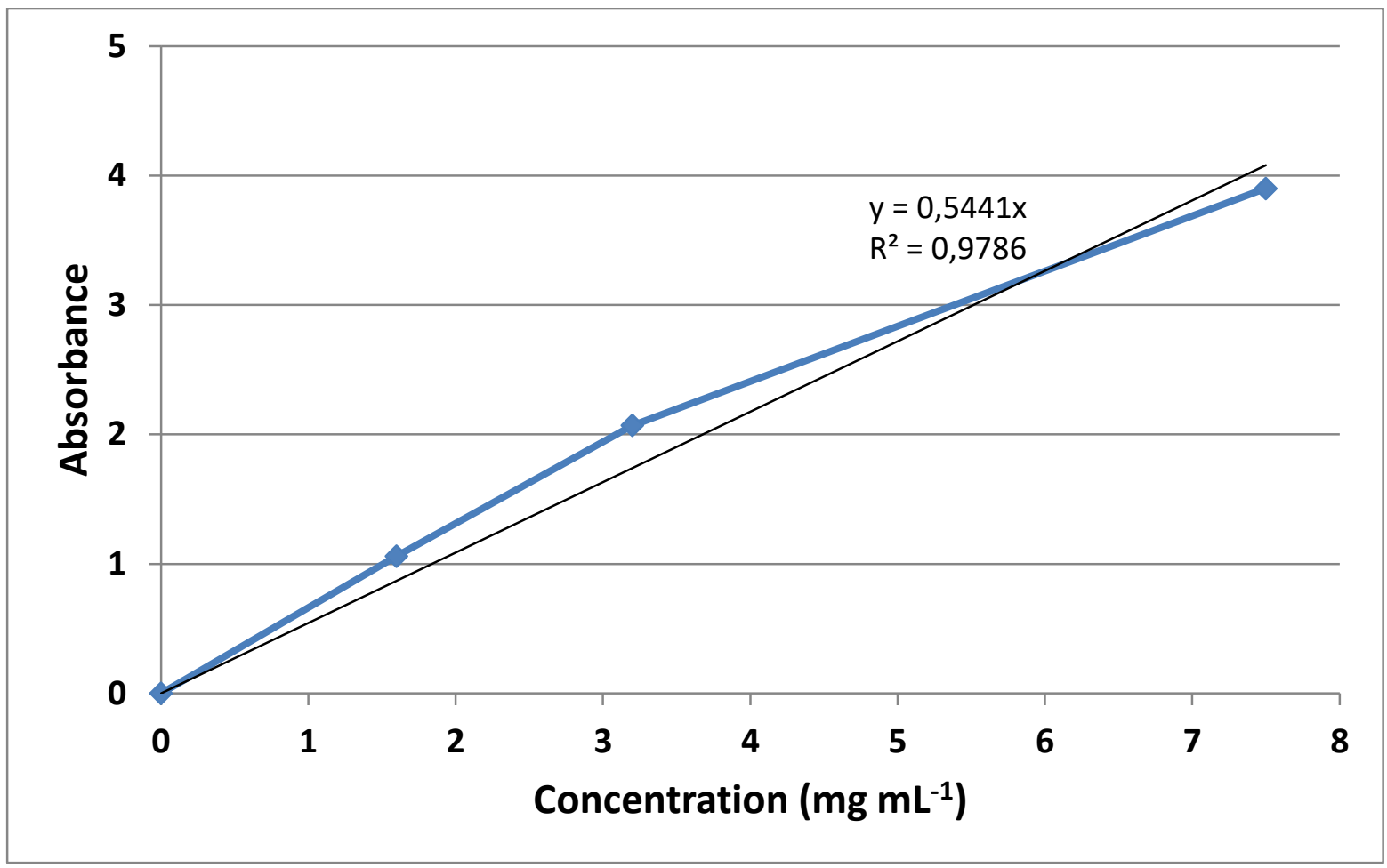

Figure 2. Calibration curve using glucose as standard reducing sugar.

Table 1. Sugar amounts of hazelnut shell, rhododendron branch and rhododendron leaf biomass after enzymatic saccharification by $\beta$-xylanase

\begin{tabular}{lcc}
\hline & Absorbance (OD540) & Concentration (mg $\mathbf{~ m L}^{-\mathbf{1}}$ ) \\
\hline Hazelnut shell & 0.4604 & 0.8461 \\
Rhododendron branch & 0.3796 & 0.6976 \\
Rhododendron leaf & 0.1962 & 0.3605 \\
\hline
\end{tabular}

The hydrolysis of hemicelluloses was carried out by enzymatic process is a very complex process. Among the enzymes that carry out hydrolysis, the enzyme $\beta$-xylanase plays an important role. The $\beta$ xylanase enzyme is a thermophilic enzyme and utilized in many biotechnological applications due to their ability to withstand high temperatures (Frock et al., 2010).

In the previous study, it was reported that the $\beta$-xylanase enzyme of Thermotoga naphthophila showed maximum activity at $\mathrm{pH} 7.0$ and $37^{\circ} \mathrm{C}$ (Hamid and Aftab, 2019). Shi et al. (2013) found that the $\beta$-xylanase enzyme cloned from Thermotoga thermarum was expressed by Escherichia coli BL21 recombinant strain was active at $95^{\circ} \mathrm{C}$ and $\mathrm{pH} 7.0$, and by adding $5 \mathrm{mM} \mathrm{Ca}^{2+}$ but active at temperatures $55-90^{\circ} \mathrm{C}$ and $\mathrm{pH}$ ranges from $4.0-8.5$.

Zverlov et al. (1996) obtained the xylanase A gene from Thermotoga neapolitana and expressed in Escherichia coli. They reported that xylanase enzyme acts as endo-1,4/3-xylanase and this enzyme showed the highest activity at $\mathrm{pH} 5.5$ at $102^{\circ} \mathrm{C}$. Furthermore, xylanase was also stable at $90^{\circ} \mathrm{C}$ but $50 \%$ reduction in enzyme activity was observed when incubated at $100^{\circ} \mathrm{C}$ for 2 hours.

Simpson et al. (1991) isolated the endo-1,4-beta-xylanase enzyme from Thermotoga sp. The best activity for the purified xylanase was reported in the range of $\mathrm{pH} 5.0-5.5$ at $80^{\circ} \mathrm{C}$. They observed that substances such as sorbitol and xylan increase the thermal stability of the enzyme.

The molecular mass of $\beta$-xylanase obtained using SDS-PAGE was calculated to be $38 \mathrm{kDa}$. The mass analysis of the enzyme was appeared similar to the results observed in other studies. Zhou et al. 
(2011) had reported the molecular mass determination of the endo-1,4 $\beta$-xylanase enzyme obtained from the organism Streptomyces sp., was $34 \mathrm{kDa}$. At the same time, they had found that the best activity of this enzyme was observed at $50^{\circ} \mathrm{C}$ and $\mathrm{pH}$ 7.0. Similarly, Shi et al. (2014) found the molecular mass of the endo-1,4- $\beta$-xylanase enzyme cloned from Thermotoga thermarum and expressed in Escherichia coli as $40 \mathrm{kDa}$. It has also been reported that the temperature and $\mathrm{pH}$ values were $80^{\circ} \mathrm{C}$ and 6.0 respectively.

The most important feature of the $\beta$-xylanase enzyme was its stability at high temperatures. Due to its stable structure, xylanases are being used in many industries and protein engineering. Studies have shown that $\beta$-xylanase enzymes cloned from various organisms have activities at high temperatures.

After $\beta$-xylanase enzyme was cloned from Thermotoga naphthophila and expressed in E. coli BL21, the biomasses were pre-treated before being treated with the enzyme. Biomass can prevent sugar production due to their structure. Lignin, which is present in the structure of the biomass, limits sugar production. So biomasses like lignin were pre-treated to remove undesired structures. In our study, acidalkaline method was used for the pretreatment stage.

Singh et al. (2015) compared the acid-alkali pre-treatment method with other existing pretreatment processes. It has been emphasized that the alkaline pretreatment is very effective in removing the lignin structure present in biomass and at the same time increases the digestibility of cellulose. Luo et al. (2014) investigated many pre-treatment methods. When these studies were examined, the most effective pre-treatment method was selected in our study.

In the present study, after the optical densities of the hazelnut shell, rhododendron branch and rhododendron leaf biomass to be saccharified after the pretreatment stage, the amount of sugar produced was calculated. Different amounts of concentrations of glucose were used as standard. Biomasses of rice straw, wheat straw, sawdust, and Saccharum munja were treated with $\beta$-xylanase enzyme by Hamid and Aftab (2019) and then saccharified to examine concentration of sugar obtained from the biomasses. The amounts of sugar released were reported as $1.52 \mathrm{mg} \mathrm{mL}^{-1}, 3.2 \mathrm{mg} \mathrm{mL}^{-1}, 1.92 \mathrm{mg} \mathrm{mL}^{-1}, 2.96 \mathrm{mg} \mathrm{mL}^{-1}$ and $1.16 \mathrm{mg} \mathrm{mL}^{-1}$ respectively. The difference from our study is that they use xylose as a standard.

In our study, amount of sugar released was calculated as $0.8461 \mathrm{mg} \mathrm{mL}^{-1}$ in hazelnut cob, 0.6976 $\mathrm{mg} \mathrm{mL}^{-1}$ rhododendron branch and $0.3605 \mathrm{mg} \mathrm{mL}^{-1}$ rhododendron leaf. Similar to our study, Zafar et al. (2016) treated the xylanase enzyme obtained from Bacillus licheniformis with straw, rice straw, and sugarcane substrates. It was reported that the amount of sugar released was wheat straw $1.95 \mathrm{mg} \mathrm{mL}^{-1}$ rice straw $1.92 \mathrm{mg} \mathrm{mL}^{-1}$ suggarcane bagasse $2.20 \mathrm{mg} \mathrm{mL}^{-1}$. The method they used to determine the sugar produced in the confectionery process was the same as we used in our study.

Haq et al. (2012) obtained xylanase enzyme by cloning endo-1,4- $\beta$-xylanase gene from Thermotoga petrophila organism. Birchwood was used as a substrate for the xylanase enzyme. The activity of the enzyme on the substrate was measured as $3.5 \mathrm{mg} \mathrm{mL}^{-1}$.

Pinar et al. (2017) have studied the effect on the enzymatic hydrolysis of the nut shell, one of the most abundant woody cellulosic agricultural residues produced in Turkey. The enzyme used was not produced from any organism and was purchased commercially. Cellulase enzyme activity on the hazelnut shell has been reported to be $1.32 \pm 0.11 \mathrm{~g} \mathrm{~L}^{-1}$.

There is no significant difference in the amount of sugar obtained in our study compared to different biomass or the same biomass. The reason why it differs from other results is due to the difference in methods that utilized total amount of enzymes and substrates.

Hosgun et al. (2017) reported that the cellulase enzyme is active against the pretreated nutshell substrate. The researchers also mentioned that the sugar released from the nut shell is very efficient for producing bioethanol. In order to carry out the hydrolysis phase of various biomass, they need enzymes that hydrolyze these biomasses. This step will be a cost-cutting step for biofuel production. 


\section{CONCLUSION}

The most preferred feature in the industrial enzyme production stage is thermotolerance of the enzymes. The reason for this preference is that enzymes are generally used in processes with high temperatures. Among the various thermophilic enzymes, xylanase enzymes are of great importance in various industries and there are many studies for production and purification of these enzymes.

In the present study, cloning of $\beta$-xylanase was re-produced in Esherichia coli and lignocellulosic biomasses of hazelnut shell, rhododendron branch, and rhododendron leaf were used as substrates for this recombinant $\beta$-xylanase enzyme. We showed that $\beta$-xylanase enzyme can be an effective source for enzymatic hydrolysis to produce fermentable sugars from such biomasses.

Hazelnut shells and rhododendron are renewable, low-cost, high-yield raw materials for producing fermentable sugars as lignocellulosic biomass. When the results of the study are evaluated, as the- $\beta$ xylanase enzyme has thermophilic property and the substrates we use produce a certain sugar release, it can be recommended to use the $\beta$-xylanase enzyme in various industrial processes and biofuel industry.

\section{ACKNOWLEDGEMENTS}

The present study was supported by the Pak-Turk Researchers Mobility Grant Program (MEV.2017-361) in Turkey by the Council of Higher Education (YÖK) and in Pakistan by the Higher Education Commission (HEC).

\section{Conflict of Interest}

The article authors declare that there is no conflict of interest between them.

\section{Author's Contilbutions}

The authors declare that they have contributed equally to the article.

\section{REFERENCES}

Arslan Y, Saraçoğlu NE, 2010. Effects of pretreatment methods for hazelnut shell hydrolysate fermentation with Pichia Stipitis to ethanol. Bioresource Technology, 101: 8664-8670.

Dodd D, Cann, IKO, 2009. Enzymatic deconstruction of xylan for biofuel production. GCB Bioenergy, 1(1): 217.

Frock AD, Notey JS, Kelly RM, 2010. The genus Thermotoga: recent developments. Environmental Technology, 31(10): 1169-1181.

Hamid A, Aftab MN, 2019. Cloning, purification, and caharacterization of recombinant thermostable $\beta$-xylanase Tnap_0700 from Thermotoga naphthophila. Applied Biochemistry and Biotechnology, 189(4): 1274-1290.

Haq I, Hussain Z, Khan MA, Muneer B, Afzal S, Majeed S, Akram F, 2012. Kinetic and thermodynamic study of cloned thermostable endo-1, 4- $\beta$-xylanase from Thermotoga petrophila in mesophilic host. Molecular biology reports, 39(7): 7251-7261.

Hoşgün EZ, Berikten D, Kıvanç M, Bozan B, 2017. Ethanol production from hazelnut shells through enzymatic saccharification and fermantion by low-temperature alkali pretreatment. Fuel, 196: 280-278.

Jegannathan KR, Nielsen PH, 2013. Environmental assessment of enzyme use in industrial production - a literature review. Journal of Cleaner Production, 42: 228-240.

López, L, Rivas S, Moure A, Vila C, Parajó JC, 2020. Development of pretreatment strategies for the fractionation of hazelnut shells in the scope of biorefinery. Agronomy, 10(10): 1568.

Luo J, Fang Z, Smith Jr RL, 2014. Ultrasound-enhanced conversion of biomass to biofuels. Progress in Energy and Combustion Science, 41: 56-93.

Miller GL, 1959. Use of dinitrosalicylic asid reagent for determination of reducing sugar. Analytical Chemistry, 31(3): 426-428. 
Özbucak TB, Türkiş S, Çakmak A, 2009. Ordu çevresinde yayılış gösteren bazı rhododendron türleri üzerine ekolojil bir çalışma. Biyoloji Bilimleri Araştırma Dergisi, 2(2): 71-77.

Phitsuwan P, Sakka K, Ratanakhanokchai K, 2016. Structural changes and enzymatic response of Napier grass (Pennisetum purpureum) stem induced by alkaline pretreatment. Bioresourse Technology, 218: 247-256.

Pinar O, Karaosmanoğlu K, Sayar NA, Kula C, Kazan D, Sayar AA, 2017. Assessment of hazelnut husk as a lignocellulosic feedstock for the production of fermentable sugars and lignocellulolytic enzymes. 3 Biotech, 7(6): 367.

Rani S, Nand K, 1996. Development of cellulase-free xylanase-producing anaerobic consortia for use the use of lignocellulosic wastes. Enzyme and Microbial Technology 18(1): 23-28.

Shi H, Zhang Y, Li X, Huang Y, Wang L, Wang, Y, Wang F, 2013. A novel highly thermostable xylanase stimulated by $\mathrm{Ca}^{2+}$ from Thermotoga thermarum: cloning, expression and characterization. Biotechnology for biofuels, 6(1): 26.

Shi H, Zhang, Y, Zhong H, Huang Y, Li X, Wang F, 2014. Cloning over-expression and characterization of a thermo-tolerant xylanase from Thermotoga thermarum. Biotechnology Letters, 36(3): 587-593.

Simpson HD, Haufler UR, Daniel RM, 1991. An extremely thermostable xylanase from the thermophilic eubacterium Thermotoga. Biochemical Journal, 277(2): 413-417.

Singh J, Suhag M, Dhaka A, 2015. Augmented digestion of lignocellulose by steam explosion, acid and alkaline pretreatment methods: areview. Carbohydrate polymers, 117: 624-631.

Sun Y, Cheng J, 2002. Hydrolysis of lignocellulosic materials for ethanol production: a review. Bioresource Technology, 83(1): 1-11.

Topal Ş, 1985. Enzimler, Mikrobiyolojik Yolla Enzim Üretimi ve Bu Teknolojide Renni'nin Yeri. Tubitak Marmara Araştırma Enstitüsü, Gebze/Kocaeli, 26 s.

Zafar A, Aftab MN, ud Din Z, Aftab S, Iqbal I, Shahid A, ul Haq I, 2016. Cloning, expression and purification of xylanase gene from Bacillus licheniformis for use in saccharification of plant biomass. Applied Biochemistry and Biotechnology, 178(2): 294-311.

Zhou J, Shi P, Zhang R, Huang H, Meng K, Yang P, Yao B, 2011. Symbiotic Streptomyces sp. TN119 GH 11 xylanase: a new pH-stable, protease-and SDS-resistant xylanase. Journal of Industrial Microbiology and Biotechnology, 38(4): 523-530

Zverlov V, Piotukh K, Dakhova O, Velikodvorskaya G, Borriss R, 1996. The multidomain xylanase A of the hyperthermophilic bacterium Thermotoga neapolitana is extremely thermoresistant. Applied Microbiology and Biotechnology, 45(1-2): 245-247. 